\title{
UJI EFEKTIVITAS SKABISIDA EKSTRAK ETANOL DAUN SIRIH (Piper betle L.) SECARA IN VIVO TERHADAP TUNGAU Sarcoptes scabiei PADA MARMUT (Cavia porcellus)
}

\author{
Kinanti Alif Formasiyah Aisyah'1, Endah Setyaningrum¹, Gina Dania Pratami', \\ Endang Linirin Widiastuti ${ }^{1}$
}

${ }^{1}$ Program Studi Biologi, Jurusan Biologi, FMIPA, Universitas Lampung

[email korespodensi : kinantialif28@gmail.com]

\begin{abstract}
Abstact : Effectiveness Test of Scabiside Ethanol Extract of Betel Leaf (Piper bet/e L.) in vivo against Sarcoptes scabiei Mites in Guinea Pigs (Cavia porcellus). Unhealthy marmot environment is one of the factors that can cause disease. One such disease is known as scabies. Scabies is caused by Sarcoptes scabiei mites that attack animals, especially on the skin. The aim of the study was to determine the effectiveness of ethanol extract of betel leaf (Piper betle L.) ethanol extract in vivo against S. scabiei mites in guinea pigs (Cavia porcellus). This research was conducted in October - November 2019. Sample examination, treatment and observation were carried out in the Zoology Laboratory of the Faculty of Mathematics and Natural Sciences while the making of betel leaf extract was carried out at the Botany Laboratory of the Faculty of Mathematics and Natural Sciences. The method used in this research is an experimental method with RAL (Complete Randomized Design) experiments. For scabies sample selection, microscopic examination of skin samples is carried out on guinea pigs showing clinical symptoms of scabies to confirm the presence of $S$. scabiei mites. The samples used were 27 marmot scabs which were relatively the same. In this study were divided into 3 treatments, namely positive control, negative control, and administration of $100 \%$ betel leaf extract. Data obtained were analyzed using One Way ANOVA and the results obtained $p=0,001$ which showed a significant reduction in the wide of the scab. Then proceed with the LSD test (Least Significance Different). Based on the results and discussion, it was concluded that the administration of betel leaf ethanol extract (Piper betle L.) in vivo to Sarcoptes scabiei mites in guinea pigs (Cavia porcellus) had the highest effectiveness as scabidae compared to $0.5 \% \mathrm{NaCMC}$.
\end{abstract}

Keywords: Betel Leaf Extract, Guinea Pigs, Scabies

\begin{abstract}
Abstrak : Uji Efektivitas Skabisida Ekstrak Etanol Daun Sirih (Piper bet/e L.) Secara In Vivo Terhadap Tungau Sarcoptes Scabiei Pada Marmut (Cavia porcellus). Kondisi lingkungan marmut yang kurang sehat merupakan salah satu faktor yang dapat menimbulkan penyakit. Salah satu penyakit tersebut dikenal sebagai skabies. Penyakit skabies disebabkan oleh tungau Sarcoptes scabiei yang menyerang hewan terutama pada bagian kulit. Tujuan penelitian untuk mengetahui efektivitas skabisida ekstrak etanol daun sirih (Piper betle L.) secara in vivo terhadap tungau $S$. scabiei pada marmut (Cavia porcellus). Penelitian ini dilaksanakan pada bulan Oktober November 2019. Pemeriksaan sampel, pemberian perlakuan dan pengamatan dilakukan di Laboratorium Zoologi Fakultas Matematika dan Ilmu Pengetahuan Alam sedangkan pembuatan ekstrak daun sirih dilakukan di Laboratorium Botani Fakultas Matematika dan Ilmu Pengetahuan Alam. Metode yang digunakan dalam penelitian ini adalah metode eksperimental dengan percobaan RAL (Rancangan Acak Lengkap). Untuk pemilihan sampel skabies, dilakukan pemeriksaan sampel kulit secara mikroskopis pada
\end{abstract}


marmut yang menunjukkan gejala klinis skabies untuk memastikan adanya tungau $S$. scabiei. Sampel yang digunakan sebanyak 27 keropeng marmut yang relatif sama. Dalam penelitian ini dibagi menjadi 3 perlakuan, yaitu kontrol positif, kontrol negatif, dan pemberian ekstrak daun sirih. Data yang diperoleh di analisis menggunakan One Way ANOVA dan didapatkan hasil $p=0,001$ yang menunjukkan adanya pengurangan lebar keropeng yang bermakna. Kemudian dilanjutkan dengan uji LSD (Least Significance Different). Berdasarkan hasil dan pembahasan maka disimpulkan bahwa pemberian ekstrak etanol daun sirih (Piper betle L.) secara in vivo terhadap tungau Sarcoptes scabiei pada marmut (Cavia porcellus) memiliki efektivitas yang paling tinggi sebagai skabisida dibandingkan dengan NaCMC 0,5\%.

Kata kunci : Ekstrak Daun Sirih, Marmut, Skabies

\section{PENDAHULUAN}

Penyakit kulit merupakan jenis penyakit yang sering menginfeksi marmut, terkadang marmut yang terserang penyakit kulit tampak baik-baik saja. Namun penyakit yang menginfeksi $40 \%$ pada area tubuh marmut dapat mematikan. Penyakit kulit yang sering menginfeksi marmut adalah skabies. Hewan yang sering terinfeksi skabies adalah kambing, domba, kerbau, sapi, kelinci, dan marmut (Colville dkk., 2002).

Skabies merupakan penyakit kulit yang lebih dikenal dengan nama kudis, budukan, gatal agogo atau gudig (Ronny, 2010). Penyakit ini disebabkan oleh tungau kecil spesies Sarcoptes scabiei (Sutanto dkk., 2008). Penyakit kulit ini biasanya menyerang hewan dan manusia.

Pengobatan skabies dengan obat dari yang murah sampai yang mahal dalam pelaksanaanya umumnya memerlukan kesabaran dan ketekunan agar penyakit tidak kambuh kembali (Hartati, 2001). Banyaknya produk kimia yang bahan-bahannya teresidu menjadi bahan yang tidak dapat didegradasi oleh lingkungan menyebabkan perlunya solusi untuk pemecahannya. Salah satu produk kimia yang berbahaya adalah obat-obat hewan karena produk obat biasanya akan teresidu dalam tubuh hewan dan nantinya akan teresidu dalam tubuh manusia karena dikonsumsi. Karena hewan rentan terhadap penyakit tentunya sistem pengobatan hewan sangat penting diterapkan (Utami dkk., 2008). Oleh karena itu, perlu dicari obat alternatif yang relatif murah sekaligus mudah disediakan di lingkungan sekitar untuk menanggulangi penyakit skabies ini. Salah satu pilihan yang tepat adalah pemanfaatan daun sirih.

\section{METODE}

desain Penelitian ini menggunakan rancangan percobaan Rancangan Acak Lengkap (RAL). Bahan yang digunakan dalam penelitian ini adalah 27 keropeng pada marmut yang terinfeksi Sarcoptes scabiei diperoleh dari peternakan Berkah Mulia Labuhan Ratu, daun sirih (Piper betle L.), aquades, etanol 96\% sebagai pelarut pada proses maserasi, NaCMC 0,5\% sebagai kontrol negatif, dan obat skabies (Sulfadex) sebagai kontrol positif.

Pembuatan ekstrak daun sirih dilakukan dengan metode maserasi. Metode maserasi merupakan proses ekstraksi zat aktif yang dilakukan dengan cara merendam serbuk dalam pelarut aktif yang sesuai, selama beberapa hari pada suhu kamar yang terlindung dari cahaya, biasanya pelarut yang digunakan adalah etanol (Mujahid dkk, 2008). Daun sirih yang diperoleh dibersihkan dengan air 
mengalir, dan dikeringkan anginkan selama 2 kali 24 jam. Kemudian, daun sirih dimasukkan ke dalam oven selama

2 jam dengan suhu $45^{\circ} \mathrm{C}$. Daun yang kering dihaluskan menggunakan blender dan diayak untuk mendapatkan serbuk (simplisia). Setelah itu, di masukkan 200 gr simplisia daun sirih yang dicampur dengan 2 liter etanol $70 \%$ kedalam beaker glass, kemudian ditutup menggunakan plastik. Kemudian diamkan selama 1 kali 24 jam. Rendaman simplisia tersebut kemudian disaring menggunakan kertas saring hingga menghasilkan cairan yang terbebas dari simplisia. Kemudian cairan dipekatkan dengan menggunakan alat rotary evaporator dengan suhu $49^{\circ} \mathrm{C}$, kecepatan 20 RPM dan tekanan 176 mBar sampai pelarut tidak menetes lagi. Cairan tersebut dapat dikatakan sebagai ekstrak etanol daun sirih.

Penelitian dibagi menjadi 3 perlakuan, yaitu kontrol negatif dengan menggunakan $\mathrm{NaCMC} 0,5 \%$, kontrol positif menggunakan obat skabies (Sulfadex) dan ekstrak etanol daun sirih. Pada penelitian ini perhitungan sampel menggunakan Rumus Federer (Gaspers, 2007). Berdasarkan perhitungan maka tiap perlakuan terdiri atas 9 ulangan. Pengamatan pada marmut dilakukan sehari sekali selama 9 hari. Pengamatan ini dilakukan dengan cara mengan tanda-tanda kesembuhan. Penilaiaı kesembuhan skabies dilakukan dengan mengukur lebar keropeng menggunakan jangka sorong. Data pengamatan dihitung dan diakumulasikan dengan perangkat software Minitab, kemudian dianalisis dengan menggunakan uji one-way ANOVA, apabila ada perbedaan bermakna maka dilanjutkan dengan Uji LSD (Least Significance Different) dengan taraf signifikan $a=5 \%$.

\section{HASIL}

\section{Perbandingan Kondisi Lebar Keropeng Marmut}

Hasil pengamatan pengurangan lebar keropeng sebelum dan sesudah

diberi perlakuan selama 9 hari dapat dilihat pada Tabel 1.

Tabel 1. Pengurangan lebar keropeng marmut sebelum dan sesudah diberi perlakuan

\begin{tabular}{l|l|c|l}
\hline No. & $\begin{array}{l}\text { Jenis } \\
\text { perlakuan }\end{array}$ & $\begin{array}{l}\text { Lebar keropeng sebelum } \\
\text { diberi perlakuan (hari ke-1) }\end{array}$ & $\begin{array}{l}\text { Lebar keropeng sesudah } \\
\text { diberi perlakuan (hari ke-9) }\end{array}$ \\
\hline 1. & $\begin{array}{l}\text { Kontrol } \\
\text { negatif } \\
\text { dengan } \\
\text { diberi } \\
\text { NaCMC } \\
0,5 \%\end{array}$ & & \\
\hline
\end{tabular}




\begin{tabular}{l|l|l|l|l|}
\hline 2. & $\begin{array}{l}\text { Kontrol } \\
\text { positif } \\
\text { dengan } \\
\text { diberi } \\
\text { Sulfadex }\end{array}$ \\
\hline 3. & $\begin{array}{l}\text { Ekstrak } \\
\text { etanol } \\
\text { daun sirih }\end{array}$ & & & \\
\hline
\end{tabular}

2. Pemeriksaan Keropeng Marmut secara Mikroskopis

Pemeriksaan keropeng marmut secara mikroskopis dilakukan dengan tujuan untuk melihat jenis parasit penyebab skabies. Dari hasil identifikasi menggunakan buku

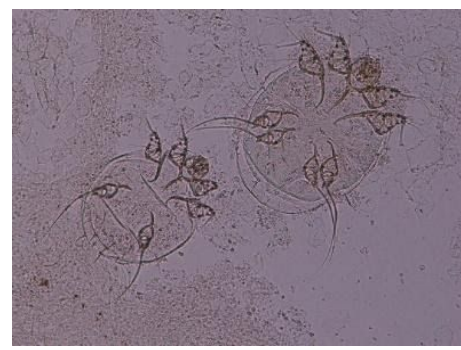

(a) kunci identifikasi Veterinary Parasitology MA Taylor dkk., (2016) ditemukan parasit berupa tungau dengan jenis Sarcoptes scabiei pada marmut (Gambar 1).

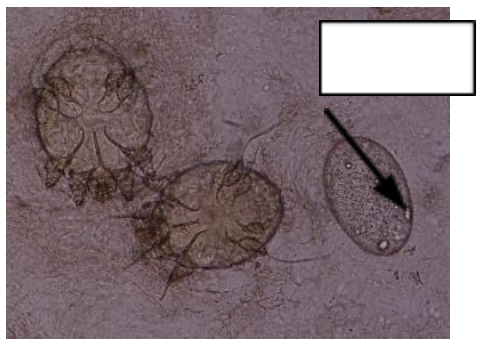

(b)

Gambar 1. Sarcoptes scabiei

Keterangan :

a. Sarcoptes scabiei dengan perbesaran 100X

b. Sarcoptes scabiei dan telur dengan perbesaran 100X

3. Uji Efektivitas Skabisida terhadap Pengurangan Lebar Keropeng Marmut

Hasil uji efektivitas skabisida ekstrak etanol daun sirih terhadap lebar keropeng marmut yang terinfeksi S.scabies menunjukkan bahwa efektivitas skabisida yang paling efektif terdapat pada perlakuan ekstrak etanol daun sirih dibandingkan kontrol negatif ( $\mathrm{NaCMC}$ $0,5 \%$ ) dan kontrol positif (Sulfadex), selengkapnya disajikan pada Tabel 2 . 
Tabel 2. Lebar Keropeng pada Marmut (Cavia porcellus) yang terinfeksi tungau Sarcoptes scabiei

\begin{tabular}{cccc}
\hline $\mathbf{R}$ & \multicolumn{2}{c}{ Pengurangan lebar keropeng masing-masing } \\
perlakuan & $\begin{array}{c}\text { Kontrol positif } \\
\mathbf{( m m )}\end{array}$ & $\begin{array}{c}\text { E. E Daun } \\
\text { Sirih } \\
(\mathbf{m m})\end{array}$ \\
\cline { 2 - 4 } & $\begin{array}{c}\text { Kontrol } \\
\text { negatif }\end{array}$ & & \\
\hline 1 & 1.32 & 0.69 & 1.04 \\
2 & 1.36 & 1.07 & .84 \\
3 & 1.30 & 1.11 & .47 \\
4 & 1.27 & 0.77 & 0.47 \\
5 & 1.41 & 1.11 & 0.60 \\
6 & 1.39 & 1.07 & 1 \\
7 & 1.30 & 1 & 0.20 \\
8 & 1.36 & 0.95 & 0.90 \\
9 & 1.34 & 0.77 & 0.90 \\
\hline Rerata & $\mathbf{1 . 3 4}$ & $\mathbf{0 . 9 5}$ & $\mathbf{0 . 7 1}$ \\
\hline
\end{tabular}

Keterangan : $\quad \mathrm{P}=$ Perlakuan

$\mathrm{U}=$ Ulangan

Kontrol negatif $=$ menggunakan $\mathrm{NaCMC} 0,5 \%$

Kontrol positif = menggunakan Sulfadex

E.E daun sirih = menggunakan ekstrak etanol daun sirih

Data yang diperoleh selanjutnya ANOVA dengan indeks kepercayaan dianalisis menggunakan One-way 95\% yang dapat dilihat pada Tabel 3 .

Tabel 3. Hasil analisis One way ANOVA (Analysis of Variance) pengurangan lebar keropeng marmut setelah diberi perlakuan

\begin{tabular}{ccccc}
\hline $\begin{array}{c}\text { Sumber } \\
\text { Variasi }\end{array}$ & $\begin{array}{c}\text { Derajat } \\
\text { kebebasan } \\
\text { (db) }\end{array}$ & $\begin{array}{c}\text { Jumlah } \\
\text { kuadrat } \\
\text { (JK) }\end{array}$ & $\begin{array}{c}\text { Mean } \\
\text { kuadrat } \\
\text { (MK) }\end{array}$ & $\begin{array}{c}\text { P-Val } \\
\text { ue }\end{array}$ \\
\hline Perlakuan(A) & 2 & 1.7959 & 0.89797 & 0.000 \\
Dalam (d) & 24 & 0.8950 & 0.02729 & \\
Total (T) & $\mathbf{2 6}$ & $\mathbf{2 . 6 9 1 0}$ & & \\
\hline
\end{tabular}

Hasil analisis data menggunakan ANOVA (Tabel 3) diperoleh (P-value < $0,05)$ sehingga terdapat perbedaan pengurangan lebar keropeng yang bermakna antar ketiga perlakuan yaitu kontrol negatif, kontrol positif dan ekstrak etanol daun sirih. Selanjutnya, dilakukan Uji LSD (Least Significance Different) pada Tabel 4 untuk mengetahui pengurangan lebar keropeng tertinggi pada ketiga perlakuan tersebut. 


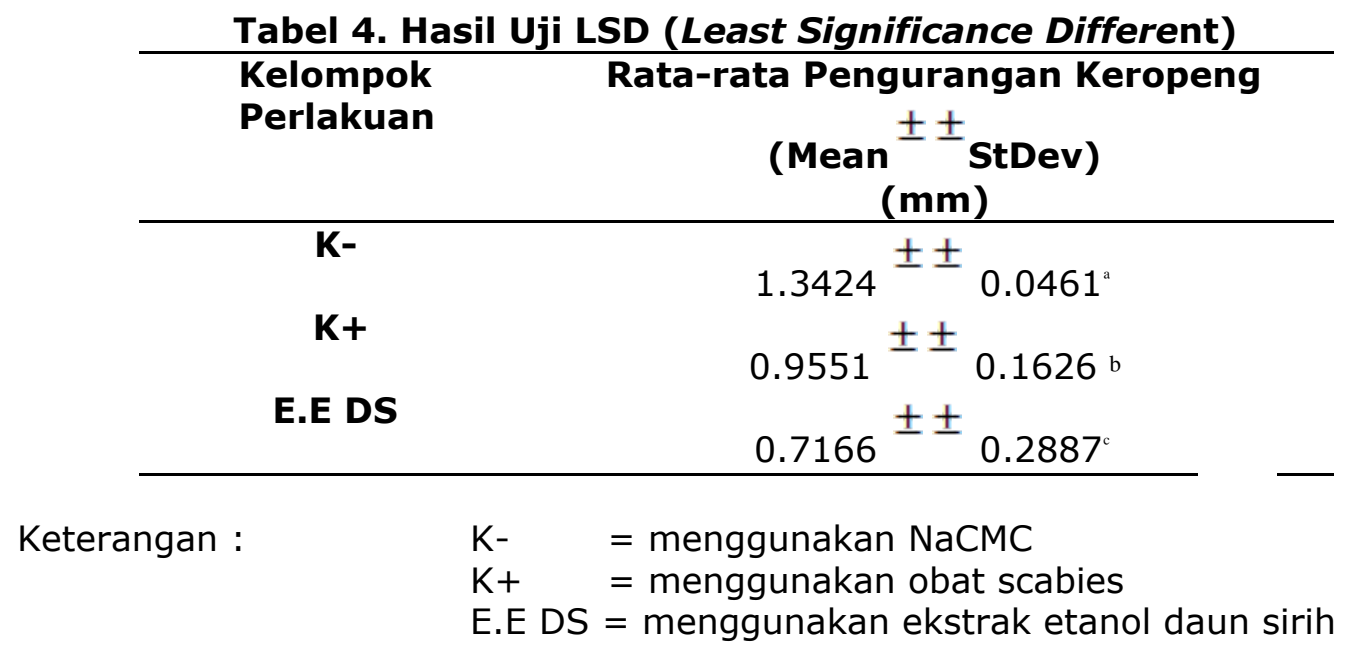

Berdasarkan hasil Uji LSD (Least Significance Different) pengurangan lebar keropeng tertinggi diperoleh pada perlakuan menggunakan ekstrak etanol daun sirih yang

\section{PEMBAHASAN}

Berdasarkan hasil penelitian, efektivitas ekstrak etanol daun sirih terhadap pengurangan lebar keropeng pada marmut ternyata lebih efektif dibandingkan kontrol negatif ( $\mathrm{NaCMC}$ $0,5 \%$ ) dan kontrol positif (Sulfadex). Hal ini ditunjukkan dengan ekstrak etanol daun sirih memiliki efektivitas yang paling tinggi dalam pengurangan lebar keropeng marmut (Tabel 4). Pengurangan lebar keropeng marmut ini diduga disebabkan oleh senyawa kimia minyak atsiri yang terdapat pada daun sirih yaitu clavikol. Hal ini sesuai dengan pendapat Heyne (1987) yang menyatakan bahwa clavikol merupakan salah satu senyawa turunan fenol dari minyak atsiri daun sirih memiliki daya insektisida lima kali lebih kuat. Cara kerja fenol dalam membunuh mikroorganisme yaitu dengan cara mendenaturasi protein sel. Sesuai juga dengan pendapat Herawati (2009) menyatakan bahwa kandungan clavikol pada daun sirih yang berasa pedas selain bersifat sebagai bakterisidal artinya ekstrak daun sirih memiliki efektivitas tertinggi dalam pengurangan lebar keropeng marmut.

dapat pula bersifat antiparasit sehingga dapat mematikan tungau Sarcoptes scabiei.

Menurut Mursito (2002) proses penyembuhan pada marmut yang terinfestasi Sarcoptes scabiei juga disebabkan adanya senyawa aktif yang berasal dari daun sirih yaitu saponin dan tanin yang bersifat sebagai antiseptik pada luka permukaan, bekerja sebagai bakteriostatik yang biasanya digunakan untuk infeksi pada kulit, mukosa dan melawan infeksi pada luka dan juga flavonoid selain berfungsi sebagai bakteriostatik juga berfungsi sebagai anti inflamasi.

Hal ini juga didukung oleh Reddy dkk (2011) bahwa kandungan saponin dan tanin berperan dalam regenerasi jaringan dalam proses penyembuhan luka. Saponin merupakan salah satu senyawa yang mampu memacu pembentukan kolagen, yaitu protein struktur yang berperan dalam proses penyembuhan luka (Ganiswarna, 1995). 
Saponin dapat memicu Vascular Endothial Growt Factor (VEGF) dan meningkatkan produksi sitokin yang akan mengaktifkan fibroblast di jaringan luka (Kimura dkk., 2006).

Kandungan tanin mempercepat penyembuhan luka dengan beberapa mekanisme seluler yaitu membersihkan radikal bebas dan oksigen reaktif, meningkatkan penyambungan luka serta meningkatkan pembentukan pembuluh darah kapiler juga fibroblast (Sheikh dkk., 2011). Onset nekrosis sel dikurangi oleh flavonoid dengan mengurangi lipid peroksidasi. Penghambatan lipid peroksidasi dapat meningkatkan viabilitas serat kolagen, sirkulasi darah, mencegah kerusakan sel (Reddy dkk., 2011).

Berdasarkan penelitian penelitian sebelumnya penyembuhan skabies disebabkan kandungan senyawa aktif yaitu minyak atsiri, saponin, tanin dan flavonoid. Berdasarkan manfaat masing-masing senyawa tersebut penulis menyimpulkan minyak atsiri lah yang berperan mematikan agen Sarcoptes scabiei yang akhirnya menghentikan aktivitas tungau hingga permukaan luka tidak semakin memburuk sedangkan saponin, tanin serta flavanoid lah yang memberikan efek positif pada proses pengurangan lebar keropeng pada penelitian ini.

\section{KESIMPULAN}

Berdasarkan hasil dan pembahasan maka disimpulkan bahwa ekstrak etanol daun sirih (Piper betle L.) secara in vivo terhadap tungau Sarcoptes scabiei efektif sebagai skabisida terhadap marmut (Cavia porcellus) dibandingkan dengan NaCMC $0,5 \%$.

\section{SARAN}

Melakukan uji fitokimia serta mampu memformulasi dalam bentuk sediaan topikal lainnya agar dapat bekerja efektif sebagai sediaan penyembuhan skabies.

DAFTAR PUSTAKA

Colville T, J. M. Bassert. (2002). Clinical Anatomy and Physiology for Veterinary Technicians. Philadelpia : Mosby.

Ganiswarna, S. (1995). Farmakologi dan Terapi, Edisi tı UI. Jakarta.

Gaspers, V. ( 7). Metode

Perancangan Percuvaan. Armico Press:Bandung.

Hartati, N . (2001). Studi Kasus Skabies pada Kambing di Kelompok Peternak Kambing Simpay Tampomas Sumedang -Jawa Barat. Skripsi. Bogor: FKH -IPB.

Herawati, E. V. (2009). Pemanfaatan Daun Sirih (Piper Betle) Untuk Menanggulangi Ektoparasit Pada Ikan Hias Tetra. Jurnal Pena Akuatika No. 1. FPIK UNDIP. Semarang.

Heyne, K. (1987). Tumbuhan Berguna Indonesia Jilid III. Badan Litbang Kehutanan. Jakarta.

Kimura Y, Sumiyoshi M, Kawahira K, dan Sakanaka M. (2006). Effects of Ginseng Saponins Isolated from Red Ginseng Roots on Bum Wound Healing in Mice. British Journal of Pharmacology. 148-150.

Mujahid, R,. Awal, P. Nita, S. (2008). Maserasi sebagai alternatif Ekstraksi pada Penetapan Kadar Kurkuminoid simplisia Temulawak (Curcuma xanthorriza Roxb). E-Publikasi Fakultas Farmasi. 18-23.

Mursito, B. (2002). Ramuan Tradisional untuk Penyakit Malaria. PT. Penebar Swadaya, Jakarta.

Reddy BK, Gowda S, dan Arora AK. (2011). Study of Wound Healing Activity of Aqueous and Alcoholic Bark Extracts of Acacia catechu on Rats. RGUHS Journal of Pharmaceutical Sciences. 1(3) 
Ronny, P. H. (2010). Skabies Dalam: Adhi D, Mochtar H, Siti A, Editor. Ilmu Penyakit Kulit dan Kelamin Edisi Keenam. Jakarta: Balai Penerbit FK UI.

Sheikh AA, Sayyed $Z$, Siddiqui AR, Pratapwar AS dan Sheakh SS. (2011). Wound Healing Activity of Sesbania grandiflora Linn Flower Ethanolic Extract Using Ex-cision and Incision Wound Model in Wistar Rats. International Journal of Pharm Tech Research. 3(2).

Sutanto, I., I.S Ismid, P.K Syarifuddin, dan S Sungkar. (2008).
Parasitologi Kedokteran. Edisi Ke-empat. Balai Penerbit Fakultas Kedokteran Universitas Indonesia, Jakarta.

Taylor, M.A., Coop, R.L., Wall, R.L. (2016). Veterinary Parasitology, $4^{\text {th }}$ Edition. Wilwy Blackwell. UK: 221.

Utami, A.S.J., A.A.NG.B.S. Dinata dan S. Guntorn (2008). Pemanfaatan A. Cair Sebagai Obat Scabies raua Kambing. Seminar Nasional Teknologi Peternakan dan Veteriner. Balai Pengkajian Teknologi Pertanian Bali, Denpasar. 